\title{
Perceptions of Students for Gamification Approach: Kahoot as a Case Study
}

\author{
https://doi.org/10.3991/ijet.v13i02.7467 \\ Huseyin Bicen $\left.{ }^{\square}\right)$ \\ Near East University, North Cyprus \\ huseyin.bicen@neu.edu.tr \\ Senay Kocakoyun \\ Istanbul Aydın University, Istanbul, Turkey
}

\begin{abstract}
A novel learning experience that increases student motivation can be created in a learning environment that includes a gamification approach to assess competence. Student perception on gamification were surveyed to determine the best application of this method, the environment necessary for its use, and the manner by which the application should proceed. The effect of a gamification approach on student achievement through intra-class competition was assessed using quantitative and qualitative methods. In this study, the Kahoot application was the preferred gamification method used. Participating students included 65 undergraduate students studying at the Department of Preschool Teaching. The findings showed that inclusion of a gamification method increased the interest of students in the class, and increased student ambitions for success. This method was also found to have a positive impact on student motivation. Furthermore, the results of this study indicate that the Kahoot application can be used effectively for gamification of lessons. In conclusion, the gamification method has an impact on students that renders them more ambitious and motivated to study.
\end{abstract}

Keywords—gamification, perception, motivation, achievement

\section{Introduction}

In October 2010, an innovative new trend emerged $[1,2]$ in the media that aimed to improve the participation of students in classroom activities and promote particular behaviors, called gamification. The aim of gamification is to make the learning process more attractive to learners. A novel learning experience that increases student motivation can be created in a learning environment that includes competition. Motivation is an important element leading to student success in most learning designs, including gamification. Thus, a more effective learning process can be produced if gamified designs that consider the element of motivation are added to learning spaces [3]. 
The fact that traditional methods of providing motivation are no longer valid has been made evident through published psychological writings and self-help books, and by research studies [4]. What makes the gamification method more attractive is that it causes an internal trigger by changing perceptions [5]. In Daniel H. Pink's book Drive: The Surprising Truth About What Motivates Us (2012), the method by which games affect our internal motivation is clearly explained. Games are successful because they encourage users by focusing on social, cognitive, and emotional results [6]. There are games in which generally humorous elements are interspersed [[7], addressed personally, designed elaborately, and which include increasingly difficult questions. Increasing difficulty requires cognitive effort, enhanced skills, and an increase in the participation of users. Supportive experiments that are fun, engaging, and rewarding are worth incorporating into learning, particularly for Generation Y. Gamification is becoming more attractive to these age groups [8]. When questions normally expected to be difficult are presented to the student in a fun and humorous learning environment, the classroom benefits from the novel techniques.

Motivation can be examined in two different psychological space, intrinsic and extrinsic. Intrinsically motivated students do not require external motivating factors; these students provide their own motivation. External factors play a positive role in students who are externally motivated. Either positive or negative effects can be observed in environments with external factors. Examples of such factors that may affect motivation include gifts, praise, achievement, appreciation, and rewards, among others [9].

In gamification studies, it was found that apart from physical awards an internally motivated goals setting and competence could have important effects on work engagement $[10,11]$. It has been argued that computer technologies are convincing for permanent changes in human behaviors, they may have an effective role combining with motivation $[12,13]$. Gamification applications may be justified as necessary for students to think, create alternative atmospheres, and for creating a competitive environment [14].

Gamification can be explained through three distinctive concepts; dynamics, mechanics, and components [15]. Game mechanics have rules and rewards, they arouse certain feelings (curiousity, competitiveness, frustration, happiness, etc.) in the player.

In most of the gamification attempts; point, badges and leader-boards are used in order to convince the participants and change their behaviors [16]. Attention must be paid that the elements were not games and how those factors of the game are combined for making the game entertaining. Understanding the roles, motivations and behaviors of the users, requires looking beyond the game's design components such as game mechanics and dynamics [17]. The most common game mechanics are given in Table 1. Education is given as an applied result at the K-6 level. These mechanics provide game dynamics and desire, as well as motivation, and lead to the feelings outlined in table 1 .

For gamification designs to have a positive impact on educational results, the learning environment much combine dynamics, mechanics, and the appropriate components. In other words, a gamification application in which all these components are used could facilitate a needs-oriented learning process in the classroom. 
Paper-Perceptions of Students for Gamification Approach: Kahoot as a Case Study

Table 1. Game Mechanics and Game Dynamics [18]

\begin{tabular}{ll}
\hline Game Mechanic & Game Dynamic \\
\hline Points & Reward \\
Level & Status \\
Trophies, Badges, Achievements & Achievement \\
Virtual Goods & Self-expression \\
Leader Boards & Competition \\
Virtual Presents & Altruism \\
\hline
\end{tabular}

Analyzed the student differentiation in gamified education during a part of systematic, effective and long term studies [19]. Letting students choose their own ways and get their lessons from the trial and errors has been reported as very important. This can give different opportunities for students through providing alternative ways during the whole levels of the lesson for learning and grading. As the lesson improves in time, the experience occurs as more competitive if the success is signified and awarded more.

In a study aiming at analyzing the gamified learning environment according to its design, application and other variables, it was aimed to design an online learning environment which includes different gamification components and also to identify the flow, emotional participation, motivation and success of the participant on this environment and lastly to search elements which give importance to success on these online environments. A route model was tested which included the effects of variables on each other and related hypothesis and also how much did the emotional participation and motivation estimate the success was tested in the study. According to the correlation analysis results in the study; the flow and emotional participation explained $\% 68$ of the motivation variant. Also; the flow, emotional participation and motivation explained $\% 22$ of the success variant. In addition to this; the flow towards motivation and success has a positive and meaningful effect and also the emotional participation had a positive and meaningful effect on the motivation [20].

Another study aimed at determining the effects of online game Kahoot which was about scientific word learning. The objective is to analyze the effect of scientifically word learning based online game -Kahoot- on students who had difficulty in learning physical science lessons in secondary schools. The results show that; all students' word distribution increases when the Kahoot is played twice a week. The use of Kahoot increased students' focus and task behaviors. The results of student satisfaction research showed that, the students liked playing Kahoot and found it easy to use [21]. Gamification is not only limited in terms of game design and game research [22]. Many scientists wanted to have a more systematic research about the gamification tools, tools and methods [23, 24].

This research aims to allow students to evaluate the Kahoot application integrated into the existing learning environment. The Kahoot application is the most preferred gamification program and our goal was to determine the effect of this gamification approach on student achievement and determine their perception. 


\section{Practice}

Kahoot, is a popular e-learning tool that can be easily used for providing metacognitive support, liveliness in class and student attendance in higher education which need limited lecturers and student education. The free online learning platform has been accepted worldwide with more than 30 million users and it is based on behavioral design methodologies and is current user centered [25]. Kahoot is an educational software example using game based pedagogy that has possibility for preparing online questionnaires, discussions or exams as well as providing students to cooperate in terms of research topics [26].

Kahoot is a learning game conducted in the classroom with the student. It can be defined as the response system of the student. Multiple choice questions may be formulated in debate format using the Kahoot application, and can be played with all students [27-29]. In the Kahoot application, the students press a button for the right answer to a question prepared before the class and projected on the board using an internet-enabled device (e.g., tablet, laptop, mobile phone, etc.). Students receive points for every correct answer given. If the classroom activity is well prepared, students willingly play along and motivation in the classroom is increased.

In a study titled as "Using Kahoot! in the Classroom to Create Engagement and Active Learning: A Game-Based Technology Solution for eLearning Novices" it has been shown that the undergraduate and graduate students were satisfied with the use of this game according to their answers and experiences regarding the use of Kahoot [25].

Kahoot is an easy program to join, and can be used to create quizzes with an interface designed in English. Teachers must sign up on "getkahoot.com" to create a simple game environment, but students are not required to sign up. The program is free and simple to join. The Kahoot application is easily formed after signing up and games created and shared by other users can be seen. Approved Kahoot games can be used in classroom activities. Future study questions equivalent to classroom lecture notes can be prepared by Kahoot. Each student determines his/her own nickname when logging in. Students whose nicknames appear on the board show increased motivation, ensuring more active participation. The tables allow the possibility of solving problems faster and of viewing them on the screen.

The ability for students to log in without downloading the application is another advantage. Kahoot is a program into which various media can be integrated, such as videos. A classroom discussion environment can be easily constructed for students by presenting them with visual media accompanied by music, sound, and photographs. However, like other programs Kahoot has limitations. For example, access to Wi-Fi is a requirement may cause communication gaps in classroom activities. below:

The stages of signing up on this platform and creating a basic level quiz are given

1. A free account is created on getkahoot.com.

2. The user chooses from the quiz, discussion, or survey options. A name is given to the Quiz and the user returns to the home screen, where answers are entered. 
3. Questions (+add question on the bottom right) and answers (incorrect under the right answer should be changed to correct) are added. After adding questions, the time is set and settings then clicked on.

4. The language and primary audience sections are selected and cover image is clicked. Choosing a cover photo is optional.

5. The quiz is ready to be taken after clicking done.

\subsection{Teaching the Lessons}

The teacher shared the course content questions in the classroom with the Kahoot online question-and-answer technique to repeat and reinforce the topics for the last 20 minutes of each lesson. Below is a description of how to handle lessons with the Kahoot application in the classroom.

\section{How to play Kahoot in the class?}

1) Choose Kahoot that you want to play: Teacher logs into his/her Kahoot account on the computer connected to the projection, as shown in Fig. 1.

Kahoots are formed on "My Kahoots" before or Kahoot games created by other users can be listed. A new Kahoot can also be created, as shown in Fig. 2.

Kahoot that you want the students to play can be launched by clicking on "play" button. Launch "launch" screen will appear.

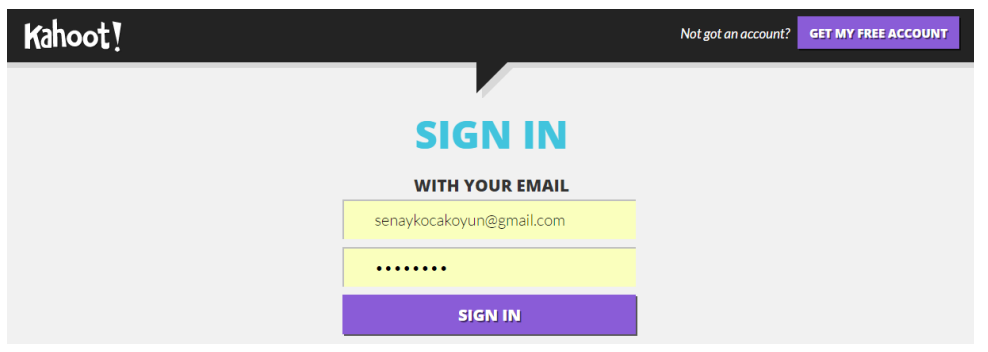

Fig. 1. Sign In

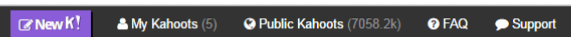

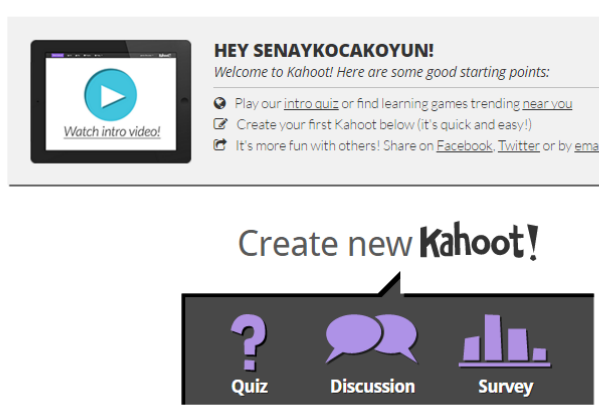

Fig. 2. Create a new Kahoot 
2) Reflect the game with projection: Game is projected on the board by the computer connected to the projection in a way that all the classroom can see. Students are asked to have their usable devices (tablet, mobile phone and computer) ready in advance. All devices that have access to the internet can be used. Mobile applications for mobile phones and tablets of Android and IOS operating systems are also available. Various options are available for teachers in this field. Randomize Order of Questions and Randomize order of answers in each question are specific options for teachers. Moreover, it offers additional options such as Advanced Options. Automatically move through questions feature can be adjusted. Game will start with the participation of students when clicked on Launch, as shown in Fig. 3.

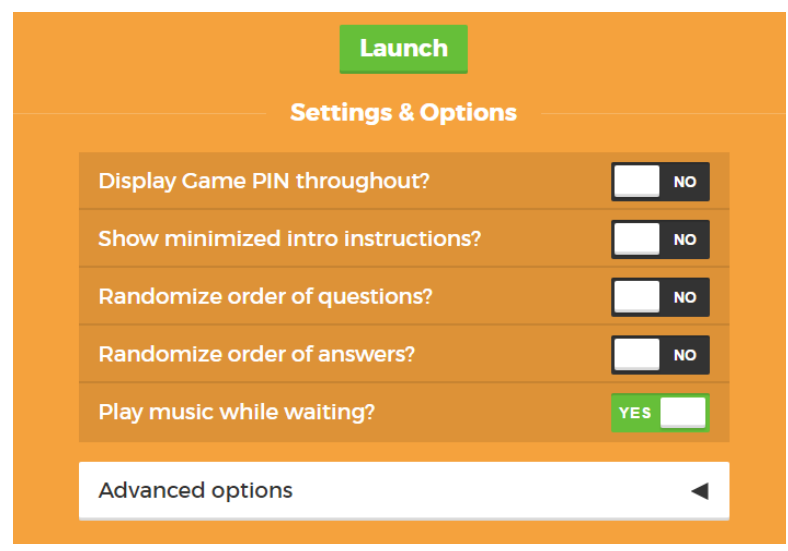

Fig. 3. Launch Game

3) Students join the game: Students do not need to sign up. They can directly play the game. A randomly created password is shown on the screen of the teacher connected to the projection. The password given after how the students will join the game is explained will be valid for this session only, and a new password will be created for each game. Students are expected to log in on kahoot.it, write their password and then write their "nicknames" for the game and enter the game. The names and number of the students who entered the game are shown on the screen of the teacher, as shown in Fig. 4. After all the students join the game, game is started by Start Now button.

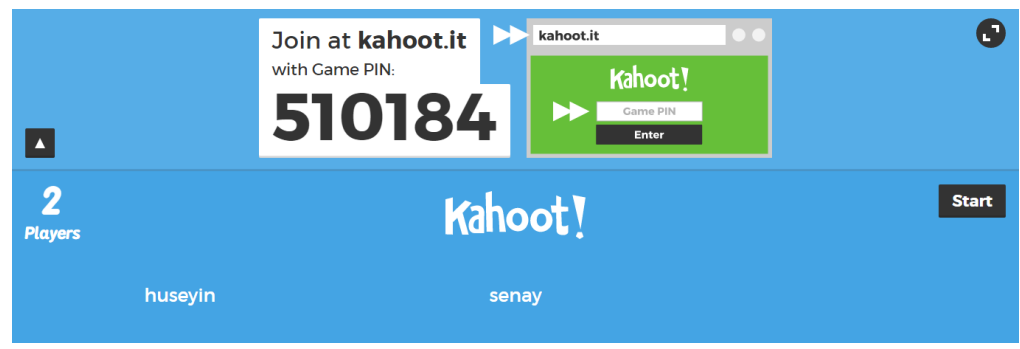

Fig. 4. Participation of students in the game 
Students get higher points depending on their speed. In the beginning, only the question is shown for 5 seconds. In this way, students are expected to think. Then, picture, video or answer options depending on the question are shown and then the timer starts. Four different shapes in four different colors will be seen on the devices of students representing multiple choice questions. When they click on the button with their right answers, the timer will continue for their friends to answer. When the time ends, the results will be automatically shown in the classroom.

4) Obtain feedback for the question: Information about the general level of the class was obtained. The number of students who gave the correct answer to the question asked was seen in Fig.5. The information bar that indicates the number of students who chose each answer choice also gave the number of students who answered the question incorrectly or confused the answers. In this case, teacher has the right to start a classroom discussion or to review the topic. The reason why these questions are answered wrong is discussed after each activity. Moreover, the students could see whether they answered the questions correctly, their scores and their position in the ranking. The rankings of the students were shown in the scoreboard when clicked on Next.

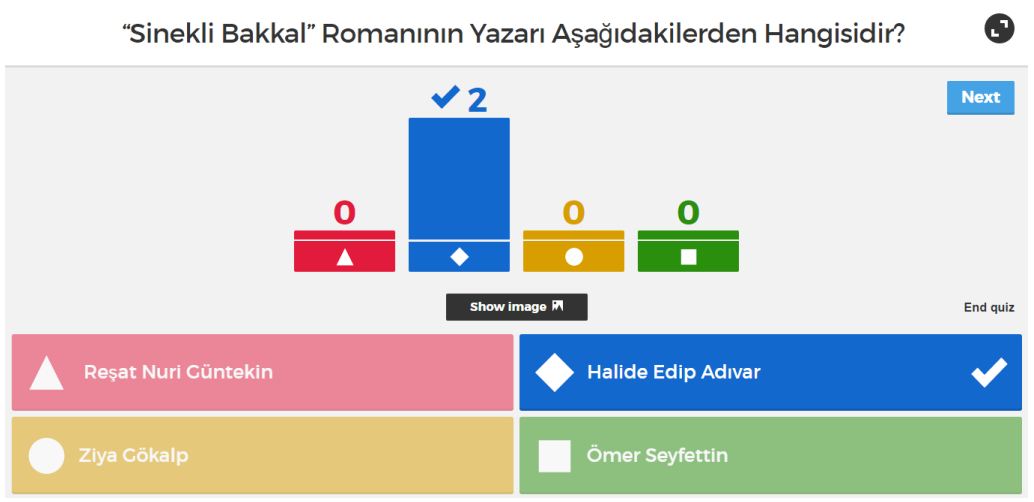

Fig. 5. Obtain feedback for the question

5) Scoreboard: First five players were shown on the scoreboard respectively after each question. Lower rankings were not shown regardless of the number of students in the class. Each question is worth up to 1000 points. As the timer works, scores start to decrease accordingly with the time. The faster the questions are answered, the higher the obtained scores are. The scoreboard shows the points collected until that moment, as shown in Fig. 6.

Teacher must click on Next button to move to the next question. The student who clicked on End button and won was seen. The name of the winner students is seen on the board in a big font and this motivates the students more. At this stage, the students are asked to evaluate their experience for the final feedback. By clicking on Feedback and Results button in Fig. 7. the way how the students felt in this exercise can be seen. 


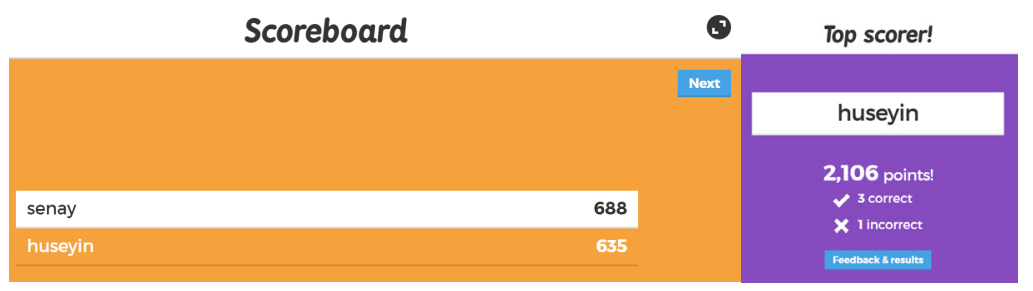

Fig. 6. Scoreboard and Feedback \& Results

Evaluate the experience: At the end, all the feedback obtained from all the answers is shown simultaneously on the board. Final results they can be seen by the "final results" button.

- How fun was it? "How fun was it?" Rating from 1 to 5

- Did you learn something? "Did you learn something?" Yes - No

- Do you recommend it? "Do you recommend it?" Yes - No

- How did you feel? "Tell us how you feel” Happy - Normal - Sad

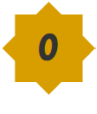

Rating

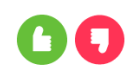

Learning

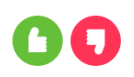

Recommend

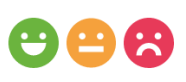

Feeling

Fig. 7. Evaluating experiences

6) Download the results: While the final version of the scoreboard is shown on the board, each students will receive a personal feedback on his/her individual device. They will be able to see the number of questions they answered correctly, their ranking and total score. Teacher can download this scoreboard to his/her own computer. In this table, correct answers will be green, incorrect answers will be red as shown in Fig. 8.

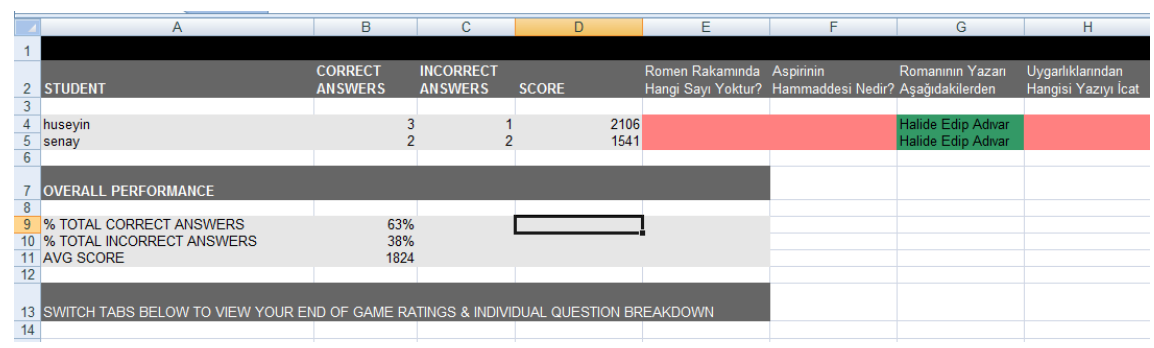

Fig. 8. Download results in your computer

In order to play the same game again, Play again button can be clicked on, in order to play another game, Play a different Kahoot button can be clicked on. 


\section{Methods}

\subsection{Purpose of the study}

The purpose of the study was to evaluate the effect of a gamification approach on student perceptions. By using the game based learning environment, the students' use of the Kahoot have been evaluated for their perspectives, the opinions and experiences of undergraduate students have been researched and lastly experimentally the students' opinions and thoughts were put forward within the qualitative and quantitative methods. For this aim; the following questions were investigated:

1. What are the general perspectives of students about gamification?

2. What are the perspectives of students about the effectiveness of Kahoot? How do the students view/evaluate the Kahoot application?

3. What do students feel are the advantages and disadvantages of gamification?

4. What are the opinions and perception of students at the end of the application based on their experience?

\subsection{Setting}

The course that implemented the Kahoot platform by the teacher. At the end of each lesson, the questions given in the course for that week were presented to the students through the Kahoot application. In addition to the experimental work, students are required to write evaluation notes in order to have qualitative data and note learning experiences about the course. Both qualitative and quantitative data were collected. To determine the perceptions of the use of the Kahoot Platform, a survey was conducted following completion of the trial phase. The results were analyzed and percentages calculated.

In this study, the effect of a gamification approach on student perfection was experimentally researched using quantitative and qualitative methods. Students who participated in the research were undergraduates studying Preschool Teaching at the Ataturk Faculty of Education. Both Scale and qualitative questions were developed by the researchers. Quantitative data were analyzed using SPSS 22. Qualitative data were analyzed using Nvivo. Qualitative data analysis was analyzed by grouping interviews in vivo codes.

\subsection{Participants}

Fifty-five female and 10 male students who were studying Preschool Teaching at the Ataturk Faculty of Education participated in the study, as total of 65 participants. The age average of $4^{\text {th }}$ year students attending the study has been found as 22 . 


\subsection{Instruments}

A scale for the measurement of the effect of a gamification approach on student achievement by classroom competition has been developed, and is formed of $3 \mathrm{di}$ mensions. In total, 65 items are available. Dimensions are divided into the following subcategories: "General Perceptions about Gamification Method" (32 items), "The Effectiveness of Kahoot Application" (23 items), and "Evaluation of Kahoot Environment" (10 items). Three dimensions are also evaluated by students by using a 5point Likert-type scale (completely agree, agree, indecisive, disagree, and completely disagree). An answer of "Completely agree" by the student is associated with a score of 5 points. A validity and reliability study of the scale was performed, and the Cronbach alpha value for internal consistency was 0.96 . The qualitative aspect of the study research consists of 4 questions. These questions are as follows: "In which lessons can gamification be used?" "Were the performed activities remarkable? Why?" "What are the advantages and disadvantages of gamification method?" And "how did you feel about being in continuous competition with your friends?" The duration for gathering all answers for questions and to direct them, has been recorded through the oral interview and these interviews later saved on the documents. Afterwards these qualitative data were analyzed using Nvivo.

\subsection{Data analysis}

Quantitative results are shown as the means and standard deviation (SD) and qualitative data are shown as frequencies and percentages. In this way, the effect of a gamification approach on the perceptions of students investigated.

\section{Results and Discussion}

\subsection{Student perceptions on the gamification method}

The responses given by students to questions about gamification are shown in Table 2. When a gamification method was used in all the lessons together with the Kahoot application, the students answered "completely agree" to all the questions. Examination of the data showed that inclusion of a gamification method increased the interest of students in the classroom $(\mathrm{M}=4.52, \mathrm{SD}=.58)$, and students studied more to become successful through the gamification method $(\mathrm{M}=4.33, \mathrm{SD}=.71)$. In addition, competition in the classroom was found to improve student motivation $(\mathrm{M}=4.36$, $\mathrm{SD}=.62$ ) and communication with the goal of becoming more successful in the classroom $(\mathrm{M}=4.44, \mathrm{SD}=.58)$. Using gamification methods in other classes was thought to be of likely benefit $(\mathrm{M}=4.35, \mathrm{SD}=.64)$ and using a gamification method on a smart phone made the students feel better $(\mathrm{M}=4.33, \mathrm{SD}=.69)$. The reward system was thought to be motivating $(\mathrm{M}=4.35, \mathrm{SD}=.59)$ and students improved themselves through gamification in areas that they feel deficient in by observing their achievement status $(\mathrm{M}=4.35, \mathrm{SD}=.64)$. Using a blended learning method enabled the students 
Table 2. Student Perceptions on Gamification Methods

\begin{tabular}{|c|c|c|c|}
\hline & Items & Mean & SD \\
\hline 1 & A gamification method increases my interest in the lesson & 4.52 & .58 \\
\hline 2 & I study more to become more successful via gamification methods & 4.33 & .71 \\
\hline 3 & $\begin{array}{l}\text { Being placed in competition with other students in the classroom via a gamification } \\
\text { method increases my motivation }\end{array}$ & 4.36 & .62 \\
\hline 4 & $\begin{array}{l}\text { I communicate more with my friends to become more successful via gamification } \\
\text { methods }\end{array}$ & 4.44 & .58 \\
\hline 5 & I want gamification methods to be used in other lessons as well & 4.35 & .64 \\
\hline 6 & Using a gamification method through my smartphone makes me feel better & 4.33 & .69 \\
\hline 7 & Rewards associated with gamification motivate me & 4.35 & .59 \\
\hline 8 & $\begin{array}{l}\text { The gamification method allows me to see my achievement status and improve myself } \\
\text { in the areas that I am weak in }\end{array}$ & 4.35 & .64 \\
\hline 9 & $\begin{array}{l}\text { Use of a learning method blended with a gamification method helped me to understand } \\
\text { the lesson better }\end{array}$ & 4.36 & .71 \\
\hline & Gamification methods are fun & 4.43 & .66 \\
\hline & $\begin{array}{l}\text { Performing group work with a gamification method illustrates how achievement can be } \\
\text { obtained through collaboration }\end{array}$ & 4.24 & .77 \\
\hline & Winning badges through a gamification method makes me feel important & 4.29 & .74 \\
\hline 13 & Gamification methods contribute to information exchange among friends & 4.29 & .65 \\
\hline 14 & Information can be recalled more easily thanks to gamification method & 4.33 & .64 \\
\hline 15 & I feel bad if I am unsuccessful when a gamification method is applied & 4.15 & .64 \\
\hline & $\begin{array}{l}\text { I think my reputation in the classroom improves with the badges I win though gamifica- } \\
\text { tion }\end{array}$ & 4.24 & .66 \\
\hline 17 & Each question I correctly answer improves my self-confidence & 4.38 & .62 \\
\hline 18 & Gamification methods help me to become more ambitious for success & 4.36 & .65 \\
\hline 19 & Gamification methods increase classroom competition & 4.40 & .60 \\
\hline & $\begin{array}{l}\text { Racing against time increases my speed in answering questions in the gamification } \\
\text { method }\end{array}$ & 4.50 & .64 \\
\hline & $\begin{array}{l}\text { Gamification methods make me take on more responsibilities to become more success- } \\
\text { ful in the lesson }\end{array}$ & 4.41 & .65 \\
\hline 22 & Sharing the score I obtain on social networks makes me feel better & 4.21 & .78 \\
\hline 23 & Applications used in gamification allow me to practice time-management skills & 4.38 & .65 \\
\hline 24 & Gamification methods enable me to learn difficult topics while having fun & 4.38 & .70 \\
\hline 25 & I force myself to learn when using gamification methods to improve group achievement & 4.34 & .69 \\
\hline 26 & The will to win increases by means of gamification methods & 4.43 & .70 \\
\hline 27 & Gamification methods will be successful if used in other lessons & 4.38 & .67 \\
\hline 28 & The formation of a competitive environment increases my motivation in the classroom & 4.46 & .66 \\
\hline 29 & Creating a competitive environment increases my interest in the lesson & 4.18 & 68 \\
\hline & $\begin{array}{l}\text { Using a gamification method for group work in crowded classes increases the level of } \\
\text { competition }\end{array}$ & 4.41 & .68 \\
\hline 31 & Gamification methods increase interest in the lesson in crowded classes & 4.24 & .66 \\
\hline 32 & $\begin{array}{l}\text { Gamification methods help identify areas of deficiency by collecting different data from } \\
\text { individuals in group activities }\end{array}$ & 4.40 & .68 \\
\hline
\end{tabular}


to understand the lesson better $(\mathrm{M}=4.36, \mathrm{SD}=.71)$ and students felt that the gamification method was fun $(\mathrm{M}=4.43, \mathrm{SD}=.66)$. Students felt that performing group activities using this method taught them how achievement could be obtained through cooperation $(\mathrm{M}=4.24, \mathrm{SD}=.77)$, gaining badges made them feel important $(\mathrm{M}=4.29, \mathrm{SD}=.74)$, and each question they correctly answered improved their self-confidence $(\mathrm{M}=4.38$, $\mathrm{SD}=.62)$ and helped them to become more ambitious for success $(\mathrm{M}=4.36, \mathrm{SD}=.65)$. The method increased the level of classroom competition $(\mathrm{M}=4.40, \mathrm{SD}=.60)$ and competition increased their response speed $(M=4.50, \mathrm{SD}=.64)$. Students felt that they took responsibility for becoming more successful in the lesson utilizing the gamification method $(\mathrm{M}=4.41, \mathrm{SD}=.65)$ and sharing the scores they obtained on social networks made them feel better $(\mathrm{M}=4.21, \mathrm{SD}=.78)$. The application helped students to better manage their time $(\mathrm{M}=4.38, \mathrm{SD}=.65)$ and to learn difficult topics by having fun $(\mathrm{M}=4.38, \mathrm{SD}=.70)$ Students forced themselves to increase group achievement $(\mathrm{M}=4.34, \mathrm{SD}=.69)$ and their desire to win was also increased $(\mathrm{M}=4.43, \mathrm{SD}=.70)$. The students felt that the application could be similarly successfully utilized in other lessons $(\mathrm{M}=4.38, \mathrm{SD}=.67)$ and that creating a competitive environment had the effect of increasing their interest in the lesson $(\mathrm{M}=4.18, \mathrm{SD}=.68)$. The level of motivation was thought to be higher in crowded classes $(\mathrm{M}=4.41, \mathrm{SD}=.68)$ and the gamification method was thought to identify areas of deficiency by collecting different data from individuals during group activities $(\mathrm{M}=4.40, \mathrm{SD}=.68)$.

Many researchers have found that gamification can be used to affect the motivation and behaviors of individuals [30-34]. It has been shown that individuals focus on 1 topic within the allotted period for the game, and a gamified competitive learning environment increases student motivation [30].

Research on gamification has shown that gamification can be a beneficial and remarkable tool that motivates and encourages learning, and helps with solving problems in different fields and communicating with different groups [35-37]. Gamification renders education more enjoyable by encouraging social ties, learning processes, specialization ability, ambition to achieve success in the competitive environments, competition, and enthusiasm of changing status, while motivating students to solve problems and partake in educational activities [38]. It has also been shown that gamification can play a notable technological role in changing human behavior $[12,13]$. In this study, students stated that the gamification method rendered them ambitious and accordingly increased the level of classroom competition. Gamification can be used as an appropriate method for changing human behavior.

\subsection{Kahoot Application}

The data presented in Table 3 suggest that the lessons carried out using Kahoot provide more permanent learning compared to learning in a traditional classroom environment $(\mathrm{M}=4.43, \mathrm{SD}=.58)$. The data also show that Kahoot enhances student interest in the lesson $(\mathrm{M}=4.40, \mathrm{SD}=.60)$ and has an effect on student success $(\mathrm{M}=4.49$, $\mathrm{SD}=.53)$. Creating activities using Kahoot is more interesting $(\mathrm{M}=4.46, \mathrm{SD}=.58)$ and using Kahoot leads to positive collaborative learning opportunities $(M=4.52$, $\mathrm{SD}=.66)$. Kahoot increases the productivity of the lesson $(\mathrm{M}=4.47, \mathrm{SD} .61)$ and stu- 
Table 3. The Effectiveness of the Kahoot Application

\begin{tabular}{|c|c|c|}
\hline Items & Mean & SD \\
\hline $\begin{array}{l}\text { 1. Lessons performed with Kahoot enable permanent learning compared to learning } \\
\text { memory in traditional classroom environments }\end{array}$ & 4.43 & .58 \\
\hline 2. Kahoot increases interest in the lesson & 4.40 & .60 \\
\hline 3. Kahoot improves success & 4.49 & .53 \\
\hline 4. Activities created using Kahoot are more interesting & 4.46 & .58 \\
\hline 5. Using Kahoot makes for more effective collaborative learning & 4.52 & .66 \\
\hline 6. Kahoot increases the effectiveness of the lessons & 4.47 & .61 \\
\hline 7. Kahoot allows for comfortable self-expression & 4.38 & .67 \\
\hline 8. Using Kahoot in education increases student motivation & 4.43 & .66 \\
\hline 9. Kahoot enables active learning & 4.50 & .56 \\
\hline $\begin{array}{l}\text { 10. Question techniques in the activities performed by Kahoot provides the students } \\
\text { with different perspectives }\end{array}$ & 4.58 & .55 \\
\hline 11. Kahoot improves the rapid-thinking abilities of students & 4.44 & .66 \\
\hline 12. Kahoot provides permanent learning in classroom activities & 4.58 & .52 \\
\hline 13. Timely questions in Kahoot activities increase student excitement & 4.36 & .65 \\
\hline 14. Kahoot gives students the opportunity to deliver richer content & 4.46 & .61 \\
\hline $\begin{array}{l}\text { 15. Using pictures in Kahoot applications allows the user to more easily understand the } \\
\text { content }\end{array}$ & 4.49 & .56 \\
\hline 16. Using videos in Kahoot application attracts greater student attention & 4.36 & .60 \\
\hline 17. The background audio in Kahoot is distracting & 4.13 & .58 \\
\hline 18. Sharing activities via social media increases motivation & 4.39 & .68 \\
\hline $\begin{array}{l}\text { 19. The scoring system of Kahoot increases the ambition of students to be a top-five } \\
\text { scorer }\end{array}$ & 4.35 & .71 \\
\hline 20. The use of Kahoot in the classroom encourages learners & 4.53 & .59 \\
\hline 21. The active use of Kahoot builds student courage to participate in activities & 4.46 & .63 \\
\hline $\begin{array}{l}\text { 22. Activities performed using the Kahoot application allow for easy learning of the } \\
\text { topic }\end{array}$ & 4.52 & .53 \\
\hline 23. The color harmony of the buttons in the application is remarkable & 4.52 & .61 \\
\hline
\end{tabular}

dents feel that they can express themselves more easily through the application $(\mathrm{M}=4.38, \mathrm{SD}=.67)$. Using Kahoot in education increases motivation $(\mathrm{M}=4.43$, $\mathrm{SD}=.66)$ and Kahoot provides active learning opportunities $(\mathrm{M}=4.50, \mathrm{SD}=.56)$. The question techniques in the activities performed using Kahoot offer students a different point of view $(\mathrm{M}=4.58, \mathrm{SD}=.55)$ and Kahoot improves the rapid-thinking skills of students $(\mathrm{M}=4.44, \mathrm{SD}=.66)$. Kahoot also provides permanent learning in classroom activities $(\mathrm{M}=4.58, \mathrm{SD}=.52)$, and student excitement is enhanced by the imposed time limits $(\mathrm{M}=4.36, \mathrm{SD}=.65)$. A richer content is presented by Kahoot $(\mathrm{M}=4.46, \mathrm{SD}=.61)$ and the inclusion of pictures in the Kahoot applications enables students to better understand the material $(\mathrm{M}=4.49, \mathrm{SD}=.56)$. Using videos in the Kahoot application attracts the attention of students $(\mathrm{M}=4.36, \mathrm{SD}=.60)$ but the background audio of Kahoot distracts students $(\mathrm{M}=4.13, \mathrm{SD}=.58)$. Sharing activities on social media increases 
student motivation ( $\mathrm{M}=4.39, \mathrm{SD}=.68)$ and being in the top five scorers of Kahoot increases ambition $(\mathrm{M}=4.35, \mathrm{SD}=.71)$. Using Kahoot during classroom activities encourages students $(\mathrm{M}=4.53, \mathrm{SD}=.59)$ and active use of Kahoot boosts the courage of students to participate in activities $(\mathrm{M}=4.46, \mathrm{SD}=.63)$. The activities performed using Kahoot application enable students to learn more easily $(\mathrm{M}=4.52, \mathrm{SD}=.53)$ and students feel that the color harmony of the buttons in the application is remarkable $(\mathrm{M}=4.52, \mathrm{SD}=.61)$. Adopting an approach that takes into account visual elements for effective gamification designs would increase the prestige of the design. Moreover, a gamification methods based solely on gamification factors may facilitate the design process [3]. Studies of Kahoot have shown that the application is user-friendly, and that it is a platform from which both teachers and students can benefit. Kahoot was shown to be the best application for teachers to promote students in the classroom and integrate competition into the educational environment. Kahoot encourages learning and creates a fun and competitive environment [39].

Thomas (2014), Kahoot allows fast and easy access and is recommended for educators. He stated that creating activities with Kahoot is beneficial because they can be used to review old lesson content. He also noted that Kahoot can be used in many different fields and for different forms of evaluation, including research projects and presentations [29].

Turan \& Goktas (2015) observed that one of students' most enjoyed elements in flipped classrooms is the Kahoot gamification application. In light of this, it can be concluded that gamification activities should be considered when designing lessons [40].

\subsection{The Kahoot environment}

Table 4. Evaluation of the Kahoot Environment

\begin{tabular}{l|c|c}
\hline \multicolumn{1}{c|}{ Items } & Mean & SD \\
\hline 1. Password access of the application is easy to navigate & 4.43 & .61 \\
\hline 2. Nickname access of the application is easy to navigate & 4.36 & .62 \\
3. The application can be easily used on all platforms & 4.32 & .64 \\
\hline 4. The time display of the activities in the application facilitates time management & 4.30 & .63 \\
5. Activity results in the application can easily be shared & 4.40 & .63 \\
\hline 6. Using the application through mobile devices is easy & 4.41 & .60 \\
\hline 7. Activities may easily be created in the application & 4.29 & .60 \\
\hline 8. Answers in the application can be easily given on smart phones & 4.43 & .58 \\
\hline 9. Projecting the application on a board facilitates answering & 4.46 & .61 \\
\hline 10. The design of Kahoot is simple and useful & 4.47 & .64 \\
\hline
\end{tabular}

Students generally answered "completely agree" when evaluating the Kahoot environment, as shown in Table 4. Students found that password access to the application was easy to navigate $(\mathrm{M}=4.43, \mathrm{SD}=.61)$, nickname entrance was easily provided $(\mathrm{M}=4.36, \mathrm{SD}=.62)$, and the application could be easily used on all platforms $(\mathrm{M}=4.32$, $\mathrm{SD}=.64)$. The time display for the application activities renders time management 
easy $(\mathrm{M}=4.30, \mathrm{SD}=.63)$ and the activity results are easily shared $(\mathrm{M}=4.40, \mathrm{SD}=.63)$. The application is easy to use on mobile devices $(\mathrm{M}=.4 .41, \mathrm{SD}=.60)$ and the activities in the application are easily enjoyed $(\mathrm{M}=4.29, \mathrm{SD}=.60)$. Moreover, the answers can be given easily using smart phones $(\mathrm{M}=4.43, \mathrm{SD}=.58)$ and projecting the application on the board facilitates student answering $(\mathrm{M}=4.46, \mathrm{SD}=.61)$. Finally, students felt that the design of Kahoot was simple and useful $(\mathrm{M}=4.47, \mathrm{SD}=.64)$; particularly because students are not required to create an account to access the Kahoot quizzes and education can be easily provided through any device (laptop, tablet, Android or iOS) with a web browser.

Kahoot applications are easily created in a safe, competitive, attractive, and fun environment. The dual academic and psychological aims of this application can be achieved on all platforms. Furthermore, the application has a positive impact on students, as revealed by the feedback feature. Students report feeling excited when playing Kahoot in the classroom and impatient to connect the game [39].

\subsection{Advantages and disadvantages of the gamification method}

The advantages and disadvantages of the gamification method reported at the end of the student interviews are given below.

Advantages: The answers given by the students regarding the advantages of using a gamification method are as follows: It was fun and it made me study before coming to the class, which made me feel self-confident. Getting a higher score than my friend led me to study harder and actively participate in the competition ( $\mathrm{f}=53,82 \%)$. It was exciting ( $\mathrm{f}=57,88 \%$ ). The competitive environment created many positive feelings, including excitement, desire for class participation, and an eagerness and willingness to come to class $(\mathrm{f}=51,78 \%)$. As competition- and race-containing games are preferred, these activities led us to become more active in the classroom $(\mathrm{f}=47,72 \%)$. It improved thinking skills and reduced answer response time ( $\mathrm{f}=60,92 \%)$. I felt like I was in a competition. I had the feeling that I could do it and that I could achieve a higher score $(\mathrm{f}=46,71 \%)$. It made us become more ambitious and feel like we were in a competition. It gave me the feeling that I must win. And therefore, it made me feel better $(\mathrm{f}=56,86 \%)$. We had a good time with friends. It facilitated learning $(\mathrm{f}=61$, $94 \%$ ). We had feelings of winning and losing ( $\mathrm{f}=58,89 \%$ ). It enabled us to consolidate what we learnt $(\mathrm{f}=55,85 \%)$. In other studies, students have similarly stated that they were pleased with the gamification method, with comments such as "I like the activities that were performed during the class. It made us consolidate what we learnt until now" [40]. Johns (2015) wanted university students to evaluate Kahoot in his study, due to interest in the application. He found that students generally came to the class with their own smart phones tablets and laptop computers and he had frequent opportunities for evaluation at the end of the class [41]. Gamification is a popular learning method from the perspective of students, because it allows them the opportunity to monitor themselves and engage in an enjoyable competitive environments. Gamification improves students' willingness to come to class; students who do not have their own devices can use other computers in the classroom. 
As a popular student response system, Socrative, is a free, cloud based SRS that can be accessed on phones, tablets and laptops $[42,43]$. This system provides teachers to evaluate small oral exams, personal fast quizzes and team games [44]. Like selfprepared exams, the others are also accessible as asynchronous at cafés, restaurants or places which has Internet access [45]. Kahoot is a game-like student follow-up system that would be used for making exams, discussions and questionnaires [39]. As multimedia tools such as video clips, music and images can also be added, this system is more dynamic than some other quiz generators. The students using Kahoot can save their time and take an exam so that they can compete with each other [46]. The total time needed for the right answers and their provision, is used in participant students' grading and sequencing [47]. This system has been reported as user friendly, entertaining, attractive and motivating for students [39, 46, 47].

Disadvantages: The answers given by the students regarding the disadvantages of using a gamification method are as follows: Problems with the internet connection caused problems in active participation. We remained behind because of the questions we could not answer $(\mathrm{f}=44,68 \%$ ). We could not answer some questions due to internet interruptions, although we knew the correct answers $(\mathrm{f}=43,66 \%)$. The only problem we encountered was the internet $(\mathrm{f}=54,83 \%)$. Sometimes the telephones were frozen $(\mathrm{f}=34,52 \%)$. We had problems associated with the time limit $(\mathrm{f}=42,65 \%)$. It has been argued that the only disadvantage associated with using the Kahoot application in a flipped classroom is that students can have problems connecting to the internet reliably at all locations [40]. There are also disadvantages that need to be recognized by educators and the students: there isn't any limit related to the number of character that you are going to use for questions and answers and the educators cannot ask end-to-end questions or cannot get open ended answers (this feature seems to be release very soon) [25].

\subsection{Opinions and perceptions of students resulting from their experiences}

General perceptions on gamification as a learning tool, assessed from the qualitative data collected during student interviews, are summarized below.

Gamification can be used during all lessons in which students have difficulties learning, so that students can easily learn by having fun. ( $\mathrm{F}=50,77 \%)$. Gamification can be used in preschool teaching, music and English lessons. It can be used to teach concepts in nursery schools $(\mathrm{F}=45,69 \%)$. It can be used in all fields. Through gamification, students start to have fun and enjoy lessons that they previously disliked $(\mathrm{F}=55,85 \%)$. Gamification can enable children to learn more easily, in a fun way. It is also important for the children to be self-confident in their social space and to spend time with their friends. Gamification may be difficult to employ in preschool-aged classrooms because the children are young, but it can be used when accompanied by teachers $(\mathrm{F}=48,74 \%)$. We can use gamification methods for learning and teaching activities. Gamification helps the child to develop cognitive skills, such as thinking and problem-solving, increases creativity, helps children to experience winning and losing in a competitive environment with friends, and socialize $(\mathrm{F}=45,69 \%)$. During the preschool period, gamification activities appropriate to the age group can involve 
the use of pictures. Using gamification, the teacher may create questions and answers on the topic he/she struggles with explaining. In this way, the topic could be consolidated $(\mathrm{F}=49,75 \%)$. Gamification methods can be used in all environments that have internet connection $(\mathrm{F}=55,85 \%)$ and can be used in all fields of education. It is quite an effective method for consolidating topics, imparting a feeling of competition, and facilitating student socialization $(\mathrm{F}=50,77 \%)$. Gamification can be used in all lessons in primary and high schools. It is likely to be particularly useful for increasing the competition in numerical lessons $(\mathrm{F}=43,66 \%)$.

Gamification can be used for various educational reasons and in all lessons. Students learn topics more easily, and tackle difficult material in a fun way; consequently, it was concluded that gamification would be an appropriate learning method for all fields. Similar results were also found in a different study. Although numerical games were primarily used, gamification can be applied to many cases in daily life [48]. Students also reported that English could be used in learning. Motivation, one of the most important factors in foreign language teaching, is defined as a power that initiates and facilitates the language-learning process $[49,50]$. Investigation of the evaluations of students from a different study revealed that the gamification application Kahoot is one of the most popular applications. It was concluded that students like to come to the class prepared, and they are motivated by the presentation of unexpected questions. Turan \& Goktas (2015) also reported that students like the Kahoot application, as well as the fact that lessons are applied [40].

\section{Conclusion}

Rapid developments in technology can lead to the formation of a competitive environment, and this competitive formation can be harnessed through use of a gamification method in the classroom. In this study, student opinions on issues in the application of gamification methods, the environments that gamification should be used in, and the method by which gamification should be carried out were assessed. The data indicate that gamification of learning heightens student interest in the lesson, and encourages students to become more ambitious for success. Simultaneously, inclusion of gamification approached has a positive effect on student motivation. The students who felt that collaboration was very important during gamification supported and helped each other in learning. The students who could join this application by means of smart phones stated that the reward system increased motivation. Students were able to see their achievement status through gamification, and improve themselves in the topics in which they are deficient; moreover, combining a gamification approach with a blended learning method helped students to better understand the lesson. Winning badges made students feel important, and students found it easier to remember information when it was presented in a gamified manner. Competition helped students to improve their response time and enabled them to learn topics that were difficult to understand. These findings suggest that gamification can be effectively integrated into lessons using the Kahoot application. The ease of using Kahoot is one of its greatest advantages. Students stated that gamification could be easily used in all fields and 
they reported that this method increased student studying before coming to class. Incorporating a gamification method in the classroom effectively makes students more ambitious, leading them to study harder. The major disadvantages of the application were technical, primarily being the speed of the internet and freezing of smart phones. Teachers can organize lessons that include gamification methods in the learning environment without technology or internet problems and they can easily motivate students to participate by bringing a competitive feeling to the environment. The ability of the teacher to attract students' attention is an important driver of student motivation. Student attention can be focused on different extracurricular activities using the Kahoot application. The incorporation of various gamification activities into lessons to help students concentrate on and adapt to lessons will motivate them.

The games are naturally described and they depend on rules, and this means that the students are trying to understand educator's expectancies and also trying to observe their own progress about the learning targets with the classroom activities. In other words, the benefits of playing games can be valid for different reasons of different students. At a course in higher education, the students' perceptions at game strategies were researched and the results show that; even though the students are exposed with the game mechanics in different ways they still benefit from these strategies [51].

In terms of mobile access of university students, Wi-Fi access and the closeness of students with computer games, the games such as Kahoot is a perfect choice for education. These types of e-learning tools, provide entertainment in class, supportive concept research and the positive energy which seems to be converted to motivation and increasing meaningfulness. This e-learning platform can create an attractive environment which provides active participation and supports learning [25].

\subsection{Recommendations for individuals who use the Kahoot application}

- To maximize effective and productive teaching using gamification methods, technical deficiencies of students and teachers should be eliminated.

- Teachers may benefit from presenting gamification activities at the beginning or end of the normal lesson plan to help the students consolidate the material.

- Motivating elements other than a scoring system can be added to the Kahoot application to increase motivation.

- Creating a team spirit in the classroom that the students feel will increase motivation. Gamification applications may be designed to bring about team spirit. It is important for the teacher to try to increase team spirit.

- When developing gamification activities, researchers should design environments that will encourage the student to think. In this way, students will be more active and the lesson will be more fun.

- Teachers should use the Kahoot application such that the students enjoy the experience. Students may find it useful to know that their teachers are supportive and willing to work with them in a positive competitive environment. 


\subsection{Recommendations for researchers and further study}

- This study was conducted during the computing lesson in Preschool Teaching. It was observed that the study gamification method was embraced by students as presented by the teacher during the computing lesson. To better realize the effectiveness of gamification methods, activities for verbal lessons should also be prepared and researched.

- As students typically need activity adaptation time, future studies should investigate the time required to adapt to these kinds of activities.

- Including gamification applications where students can reveal themselves will allow students to become aware of their limitations and become more motivated in the learning environment.

- The process of integrating gamification methods into traditional education will have different effects on different audiences, including academics, school authorities, and students. Other studies of these groups should be investigated.

\section{Acknowledgements}

This work was supported by Research Fund of the Near East University. Project Number: CE044- 2015.

\section{$7 \quad$ References}

[1] Radoff, J. (2011). Gamification. Retrieved January 08, 2016, from http://radoff. $\mathrm{com} / \mathrm{b} \log / 2011 / 02$.

[2] Smith, S. (2011). An Introduction to Gamification, Retrieved April 22, 2016, from http://awesome.hubpages.com/ hub/Intro-to-Gamification

[3] Guler, C. \& Guler, E. (2015). Çevrimiçi Öğrenme Ortamlarında Oyunlaştırma: Rozet Kullanım1. Journal of Research in Education and Teaching. 4(3). 125-130.

[4] Simões, J., Redondo, R. D., \& Vilas, A. F. (2013). A social gamification framework for a K-6 learning platform. Computers in Human Behavior, 29(2), 345-353. https://doi.org/10.1016/j.chb.2012.06.007

[5] Buyukyıldırım, Ü. (2014). Oyunlaştırma (Gamification) Nedir? Retrieved January 17, 2016, from http: //www.bilim.org/oyunlastirma-gamification-nedir/

[6] Domínguez, A., Saenz-De-Navarrete, J., De-Marcos, L., Fernández-Sanz, L., Pagés, C., \& Martínez-Herráiz, J. (2013). Gamifying learning experiences: Practical implications and outcomes. Computers \& Education, 63, 380-392. https://doi.org/10.1016/j.compedu.2012. $\underline{12.020}$

[7] Coller, B., \& Scott, M. (2009). Effectiveness of using a video game to teach a course in mechanical engineering. Computers \& Education, 53(3), 900-912. https://doi.org/10.1016/ j.compedu.2009.05.012

[8] Bosworth, A. (2012). Keas: Developing a Successful Game-Based Employee Wellness Program. Games for Health Journal, 1(3), 189-191. https://doi.org/10.1089/g4h.2012.0020

[9] Zichermann, G., \& Cunningham, C. (2011). Gamification by design: Implementing game mechanics in web and mobile apps. O'Reilly Media, Inc. 
[10] Huckabee, I., \& Bissette, T. (2014). Learning made fun. Training Industry Magazine, 3235.

[11] Muntean, C. I. (2011). Raising engagement in e-learning through gamification. In Paper presented at the 6th annual international conference on virtual learning, Kelowna, British Columbia, Canada. Retrieved January 17, 2016, from www.icvl.eu/2011/disc/ $\mathrm{icvl} /$ documente $/ \mathrm{pdf} / \mathrm{met} / \mathrm{ICVL} \_$ModelsAndMethodologies_paper42.pdf

[12] Hamari, J., Koivisto, J., \& Sarsa, H. (2014). Does Gamification Work? -- A Literature Review of Empirical Studies on Gamification. 2014 47th Hawaii International Conference on System Sciences. https://doi.org/10.1109/HICSS.2014.377

[13] Hamari, J., Koivisto, J., \& Pakkanen, T. (2014). Do Persuasive Technologies Persuade? A Review of Empirical Studies. Persuasive Technology Lecture Notes in Computer Science, 118-136.

[14] Icard, S. B. (2014). Educational technology best practices. International Journal of Instructional Technology and Distance Learning. 11(3), 37-41. Retrieved March 11, 2016, from http://itdl.org/Journal/Mar 14/Mar14.pdf\#page $=41$

[15] Werbach, K., \& Hunter, D. (2012). For the win: How game thinking can revolutionize your business. Wharton Digital Press.

[16] Gadiyar A. R. (2014). Gamification 3.0: The Power of Personalization. White paper. Cognizant's Global Technology.

[17] González, C. S., Toledo, P., \& Muñoz, V. (2016). Enhancing the engagement of intelligent tutorial systems through personalization of gamification. International Journal of Engineering Education (IJEE), 32(1), 532-541.

[18] Bunchball (2010). Gamification 101: An Introduction to the Use of Game Dynamics to Influence Behavior. (2017, March 31). Retrieved April 14, 2017, from http://www.bunchball.com/gamification101

[19] Barata, G., Gama, S., Jorge, J., \& Gonçalves, D. (2017). Studying student differentiation in gamified education: A long-term study. Computers in Human Behavior, 71, 550-585. https://doi.org/10.1016/j.chb.2016.08.049

[20] Caglar, Ş. (2017). Oyunlaştırılmış Bir Öğrenme Ortamının Tasarlanması, Uygulanması ve Çeşitli Değişkenlere Göre İncelenmesi.

[21] Pede, J. (2017). The effects of the online game Kahoot on science vocabulary acquisition (Doctoral dissertation, Rowan University).

[22] Deterding, S. (2015). The lens of intrinsic skill atoms: A method for gameful design. Human-Computer Interaction, 30(3-4), 294-335. https://doi.org/10.1080/07370024. 2014.993471

[23] Deterding, S., Björk, S. L., Nacke, L. E., Dixon, D., \& Lawley, E. (2013, April). Designing gamification: creating gameful and playful experiences. In CHI'13 Extended Abstracts on Human Factors in Computing Systems (pp. 3263-3266). ACM. https://doi.org/10.1145/ $\underline{2468356.2479662}$

[24] Morschheuser, B., Hamari, J., Werder, K., \& Abe, J. (2017). How to gamify? A method for designing gamification.

[25] Plump, C. M., \& LaRosa, J. (2017). Using Kahoot! in the Classroom to Create Engagement and Active Learning: A Game-Based Technology Solution for eLearning Novices. Management Teaching Review, 2(2), 151-158 https://doi.org/10.1177/2379298116689783

[26] Sera, L., \& Wheeler, E. (2017). Game on: The gamification of the pharmacy classroom. Currents in Pharmacy Teaching and Learning, 9(1), 155-159. https://doi.org/10.1016/j.cptl. 2016.08.046

[27] Byrne, R. (2013). Free technology for teachers: Kahoot! -create quizzes and surveys your students can answer on any device. Retrieved December 12, 2015, from 
http://www.freetech4teachers.com/2013/11/kahoot-create-quizzes-and-surveysyour.html\#.VLnc78buzuU

[28] Kahoot! Game-based blended learning \& classroom response system. (2014). Retrieved January 10, 2015, from https://getkahoot.com

[29] Thomas, C. (2014). Kahoot! Retrieved January 17, 2015, from https://www.graphite.org/website/kahoot

[30] Deterding, S., Dixon, D., Khaled, R., \& Nacke, L. (2011). From game design elements to gamefulness. Proceedings of the 15th International Academic MindTrek Conference on Envisioning Future Media Environments - MindTrek '11. https://doi.org/10.1145/2181037 .2181040

[31] Hamari, J. (2013). Transforming homo economicus into homo ludens: A field experiment on gamification in a utilitarian peer-to-peer trading service. Electronic Commerce Research and Applications, 12(4), 236-245. https://doi.org/10.1016/j.elerap.2013.01.004

[32] Hamari, J., Huotari, K., \& Tolvanen, J. (2014). Gamification and economics. In S. P. Walz \& S. Deterding (Eds.), The Gameful World: Approaches, issues, applications. Cambridge, MA: MIT Press.

[33] Hamari, J., \& Lehdonvirta, V. (2010). Game design as marketing: How game mechanics create demand for virtual goods. International Journal of Business Science \& Applied Management, 5(1), 14-29.

[34] McGonigal, J. (2011). Reality is broken: why games make us better and how they can change the world. (2011). Choice Reviews Online, 49(02). https://doi.org/10.5860/CHOI CE.49-0680

[35] Deloitte (2012). Gamification: gaming gets serious. Retrieved January 17, 2016, from http://www.mediabuzz.com.sg/asian-emarketing/game-based-marketing/1678-tech-trends2012-gaming-gets-serious.

[36] Zicherman, G., \& Linder, J. (2010). Game-based marketing: Inspire customer loyalty through rewards, challenges, and contests. New York, NY: John Wiley \& Sons.

[37] Kapp, K. M. (2012). The gamification of learning and instruction: game-based methods and strategies for training and education. New York, NY: John Wiley \& Sons.

[38] Sarıtas, M.T. \& Yildiz, Ö. (2015). Eğitimde Oyunlaştırma (Gamification) ve Ters-Yüz Edilmiş Sınıflar (Sınıflar). Akademik Bilișim 2015. 4-6 Şubat Anadolu Üniversitesi.

[39] Dellos, R (2015). Kahoot! A digital game resource for learning. International Journal of Instructional Technology and Distance Learning. 12(4), 48-52.

[40] Turan, Z., \& Goktas, Y. (2015). A new approach in higher education: the students' views on flipped classroom method. Journal of Higher Education and Science, 5(2), 156. https://doi.org/10.5961/jhes.2015.118

[41] Johns, K. (2015). Engaging and Assessing Students with Technology: A Review of Kahoot!. Delta Kappa Gamma Bulletin, 81(4), 89.

[42] Dervan, P. (2014). Increasing in-class student engagement using Socrative (an online Student Response System). The All Ireland Journal of Teaching \& Learning in Higher, 6, 1801-18013.

[43] Steed, A. (2013). Technology in the classroom. Teaching Business \& Economics, 7-9.

[44] McLaughlin, T., \& Yan, Z. (2017). Diverse delivery methods and strong psychological benefits: A review of online formative assessment. Journal of Computer Assisted Learning. https://doi.org/10.1111/jcal.12200

[45] Sprague, A. (2016). Improving the ESL graduate writing classroom using Socrative: (Re) considering exit tickets. TESOL Journal, 7, $989998 \mathrm{https://doi.org/10.1002/tesj.295}$ 
[46] Graham, K. (2015). TechMatters: Getting into Kahoot! (s): Exploring a game-based learning system to enhance student learning. LOEX Quarterly, 42(3), 6-7. Retrieved from http://commons.emich.edu/loexquarterly/vol42/iss $3 / 4$.

[47] Siegle, D. (2015). Technology: Learning can be fun and games. Gifted Child Today, 38(3), 192-197 https://doi.org/10.1177/1076217515583744

[48] Bozkurt, A. \& Genc Kumtepe, E. (2014). Oyunlaştırma, oyun felsefesi ve eğitim: Gamification. Akademik Bilişim 14 Konferansı, Mersin.

[49] Clement, R., Dornyei, Z., \& Noels, K. A. (1994). Motivation, Self-confidence, and Group Cohesion in the Foreign Language Classroom. Language Learning, 44(3), 417-448. https://doi.org/10.1111/j.1467-1770.1994.tb01113.x

[50] Pintrich, P. L. \& Schunk, D. H. (1996). Motivation in education: Theory, research and applications. Englewood

[51] Alexander, C. (2017, March). Student Perceptions of Gamification in Higher Education. In Society for Information Technology \& Teacher Education International Conference (pp. 1428-1433). Association for the Advancement of Computing in Education (AACE).

\section{Authors}

Huseyin Bicen was born in Nicosia on December 31, 1986. In 2007, at the Near East University, Ataturk Faculty of Education, in Computer Education and Instructional Technologies department, as a lecturer he began lecturing computer and educational technologies related courses. Since July 2015, he has been Associate Professor on the same Department. Since October 2013, he has been Head of Distance Learning Centre and Department of Human Resources Development in Education. Hüseyin Bicen has two (2) national academic content book published by reputable publishing houses. Eight (8) of his articles was indexed at Social Sciences Index (SSCI) and thirty (30) were indexed in the Educational field indexes (ISI, British Education Index, ERIC, Science Direct, Scopus..Etc.). (huseyin.bicen@neu.edu.tr).

Senay Kocakoyun received degree in Computer Education and Instructional Technology from Near East University, Cyprus, in 2012, and the Master of Arts degree from Computer Education and Instructional Technology Near East University, Cyprus, in 2014. In the same section and she started her Ph.D. and Ph.D. still in progress. Now she is a lecturer in Anadolu BIL Vocational School of Higher Education, Computer Programming Department, Istanbul Aydın University, Istanbul, Turkey (senaykocakoyun@aydin.edu.tr)

Article submitted 24 July 2017. Resubmitted 27 September 2017. Final acceptance 13 November 2017. Final version published as submitted by the authors. 